\title{
CORPORATE IMAGE AND CUSTOMER LOYALTY IN THE DENTAL HEALTH SECTOR
}

\author{
Ali Rıza Köseoğlu ${ }^{1}$ \\ Hanifi Murat Mutlu²
}

DOI: https://doi.org/10.31410/ERAZ.2019.41

\begin{abstract}
The privatization of healthcare services has become commonplace nowadays. Many different marketing strategies are used during privatizations in order to reach the desired volume of customers. Among these marketing methods, it is believed that verbal marketing is effective in terms of influencing the preferences of customers. However, it seems that research in this field is not sufficient. In this context, the aims of this paper are to explore the effects of word-of-mouth marketing (WOM) and corporate image (CI) on customer loyalty (CL) in individuals who have undergone dental healthcare, and to investigate certain related factors. Questionnaires were prepared as the principal data collection method for the research. The study consisted of a total of 172 respondents. According to the correlation analysis that was conducted in order to analyze the relationships between WOM promotion, $C I$ and $C L$, it was found that these variables have an effective positive relationship with each other. In order to increase customer satisfaction levels and patient loyalty to health institutions, it is necessary to consider variables such as the quality of service, word-of-mouth marketing, corporate image, corporate reputation, and customer loyalty, both in terms of the basic human right to healthcare, and in terms of commercial interests.
\end{abstract}

Keywords: Word-of-mouth, corporate image, loyalty, dental health, health quality

\section{INTRODUCTION}

\footnotetext{
A ccording to Nielsen's latest 'Global Trust in Advertising' report, 92 percent of consumers trust recommendations made by friends and family more than advertising. Moreover, 88 percent of people trust online reviews written by other consumers as much as they trust recommendations made by personal contacts, while 74 percent of consumers identify word-of-mouth (WOM) promotions as a key influencer in their purchasing decisions. However, only 33 percent of businesses actively seek to receive reviews, despite the fact that a little can do a lot. When specific case studies were analyzed, researchers found that a 10 percent increase in word-ofmouth (off and online) promotions translated into a sales lift of between 0.2 and 1.5 percent $^{3}$. Even though WOM marketing has a long history in advertising, and a number of researchers have examined how it can affect purchasing decisions, research exploring the effects of electronic word-of-mouth (eWOM) promotion is still in its early stages [1]. Traditionally, word-of-mouth marketing was spread from one person to another through recommendations, but its modern version involves both targeted efforts and naturally occurring instances where users describe their satisfaction with a brand ${ }^{4}$.

$1 \quad$ Gaziantep University, Turkey

2 Gaziantep University, Department of International Trade and Logistics, Turkey

3 https:/www.nielsen.com/us/en/insights/news/2012/consumer-trust-in-online-social-and-mobile-advertising-grows.html

4 https://www.bigcommerce.com/blog/word-of-mouth-marketing/\#what-is-word-of-mouth-marketing
} 
The objective of this study is to investigate the effects of WOM promotion and corporate image (CI) on customer loyalty (CL) in the context of dental health services. The study focuses on the following research questions:

- How do WOM promotion and CI affect CL?

- Which of the variables has a stronger effect on CL?

By achieving these goals, this study will contribute both to the literature and to business management by highlighting the levels of relative importance of the research variables thought to have an impact on CL. Much research in the literature has been on the relationships between WOM promotion, CI, and CL, but these studies have essentially dealt with the retail sector. Our study focused on the health sector, primarily the dental health sector. The overall purpose of this paper is to contribute to the literature on CL and its antecedents.

\section{LITARATURE}

Dick and Basu defined customer loyalty as the relationship between the relative attitude toward an entity (brand/service/store/vendor) and patronage behavior [2]. Oliver described loyalty as "a deeply held commitment to re-buy or re-patronize a preferred product/service consistently in the future..." [3: p.34]. For our purpose, we define customer loyalty as a patient's favorable attitude toward a dental health center that results in repeat-visiting behavior. Antecedents to customer loyalty come under three categories - customer-related factors, product-related factors, and corporation-related factors. We consider customer-related factors to include WOM feedback and corporation-related factors to include CI.

WOM marketing was first characterized by Arndt [4] as oral, person-to-person communication among clients regarding a brand, product, or service, but also an organization. Buttle stated that WOM feedback can influence purchasing decisions either positively or negatively, and that negative feedback typically has a more powerful impact than positive feedback [5]. Many research findings have demonstrated that WOM promotions, such as consumer reviews, can have a significant effect on consumer behavior and purchasing decisions, as well as firm performance [6; 7]. Some studies have even identified WOM promotion as being more influential than print ads, personal selling, and radio advertising [8; 9], although Van den Bulte and Lilien [10] showed that some of these effects may have been overstated [11]. Research has demonstrated that certain factors, such as extreme satisfaction or dissatisfaction, commitment to the firm, length of the relationship with the firm, and novelty of the product, drive consumer behaviors [11]. Yeoh, Othman, and Ahmad [12] pointed out that WOM feedback has an impact on marketing strategies, whereas other researchers found an effect on consumers' purchasing decisions $[13 ; 14 ; 15]$, while others highlighted the importance of the source of trusted information $[16 ; 15]$, and of immediate feedback [17].

Gray and Balmes defined CI as the immediate mental picture that audiences have of an organization [18]. According to another definition by Lemmink, Schuijf, and Streukens [19], "CI is social or public knowledge or perceptions about a given company" [20]. Considerable academic research has showed that $\mathrm{CI}$ has a significant role in determining consumer behavior, and is particularly important in developing and maintaining customer loyalty [21]. CI is fed by various factors, such as consumer experiences, employment experiences, company-related news and comments, the variety and/or quality of products/services, and the quality of communication by related and interacted partners [20;21]. 
Eelen, Özturan, and Verlegh found that brand loyalty was significantly more strongly related with person-to-person WOM promotion than with eWOM [22]. Virvilaite, Tumasonyte, and Sliburyte investigated the relationship between WOM communication and brand equity, and found that WOM promotion had a positive relationship with brand loyalty as a component of brand equity [23]. Uslu, Durmuş, and Taşdemir explored the role of ethnicity in mobile phone purchasing decisions regarding brand loyalty and WOM feedback [24]. The results of their study showed that there were no significant differences in the WOM feedback given by German and Turkish consumers. Carpenter and Fairhurst found that the relationship between customer loyalty and WOM promotion was positive and significant [25]. In addition, they found that attitudinal loyalty serves as a mediator between consumer satisfaction and consumer WOM communication. Athavale, Banahan, Bentley, and West-Strum, meanwhile, researched the antecedents and consequences of customer loyalty to particular pharmacies [26]. They found a positive-negative linear relationship between loyalty behavior and positive-negative WOM promotion. A meta-analysis conducted by De Matos and Rossi demonstrated a significant positive effect of loyalty on WOM feedback [27]. Generally, loyal customers are more likely to give positive recommendations of a firm to reference group members than disloyal ones [28]. Several Turkish academic studies have showed that there is a positive relationship between certain customer-related factors (e.g., satisfaction, loyalty, perceived service quality, trust) and WOM promotion [29: 30; 31; 32; 33]. Our assumption is of a positive relationship between customer loyalty and word-of-mouth promotion.

\section{$\mathbf{H}_{1}$ : There is a significant and positive relationship between CL and WOM promotion.}

Wang and $\mathrm{Wu}$ investigated the effects of $\mathrm{CI}$, perceived value, and switching costs on customer loyalty in customer-provider relationships of different lengths [34]. They found that corporate image impacted customer loyalty in both newer and older relationships. Gürlek, Düzgün, and Uygur showed that CI affects CL both directly and indirectly in the extant literature, and their research findings supported those relationships [35]. According to a study by Kipkirong Tarus and Rabach, CI had a moderating effect on CL [36]. Interestingly, Andreassen and Lindestad found that CI had a stronger effect on loyalty than satisfaction did [37]. For some groups of consumers in particular, CI was the strongest driver of future intended repurchasing behavior. Moreover, analysis findings by Kaur and Soch showed that CI was an important determinant of attitudinal loyalty [38]. Lai, Griffin, and Babin tested the inter-relations between assessments of service quality, customer perceived value, perceptions of corporate image, customer satisfaction, and loyalty [39]. They argued that there was no significant relationship between CI and CL. However, Igbudu, Garanti, and Popoola posited that CI both affects loyalty and mediated in the relationship between sustainability and loyalty [40]. Their findings showed a positive effect of corporate image on customer loyalty. In academic studies whose samples were from Turkey, CI was found to have a significant effect on loyalty, satisfaction, corporate identity, and perceived service quality [ $41 ; 42 ; 43 ; 44]$. Based on these findings, we have posited the following hypothesis:

$\mathbf{H}_{2}$ : There is a significant and positive relationship between CI and CL.

\section{METHOD}

We collected data from dental healthcare patients in Hatay, Turkey. The data was collected as part of the first author's master's thesis. The convenience sampling method was used in the study, with self-administered questionnaires being utilized. We collected a total of 172 questionnaires. Each 
measure had multiple items with a 5-point summated rating scale, with anchors of 1 being "strongly disagree" and 5 being "strongly agree", except in the case of the respondents' demographics. To measure the research variables, modified versions of previously developed scales were used.

The WOM feedback variable was adopted from the work of $[31 ; 30 ; 32 ; 29 ; 45]$, and measured eight items. CI was measured using a scale that was adopted from $[41 ; 43 ; 44]$, and contained five items. The CL variable was taken from $[46 ; 47 ; 48]$, and has been commonly used in the literature.

The reliability of research constructs is sufficient according to [49: p. 24], who suggested a Cronbach's alpha value of 0.70 or better. All the constructs had acceptable reliability scores, as can be seen in Table 1.

\section{ANALYSES}

Of the 172 respondents, about 49 percent were female and 51 percent were male. The respondents were aged between 19 and 80 years. The average age was 36 years. The financial status of the respondents was categorized as upper ( 83 persons), medium (66 persons), and lower (23 persons).

Table 1 shows the means, standard deviations, Cronbach's alphas, and bivariate Pearson correlations of the constructs.

Table 1: Correlation Analyses

\begin{tabular}{|l|c|c|c|c|}
\cline { 2 - 5 } \multicolumn{1}{c|}{} & CL & WOM & CI & Cronbach's $\alpha$ \\
\hline CL & 1 & & & .93 \\
\hline CI & $.540^{* *}$ & 1 & & .92 \\
\hline
\end{tabular}

**: $\mathrm{p}<.001$; CL: Customer Loyalty; WOM: Word-of-Mouth; CI: Corporate Image

We found positive and strong correlations between CL and WOM promotion $(\mathrm{r}=.540, \mathrm{p}<.001)$ and between $\mathrm{CL}$ and $\mathrm{CI}(\mathrm{r}=.899, \mathrm{p}<.001)$. These results showed that $\mathrm{H}_{1}$ and $\mathrm{H}_{2}$ were supported.

\section{DISCUSSION, CONCLUSION, AND IMPLICATIONS}

This study focused on the relationship between customer loyalty and customer-related factors, such as WOM communication, and corporation-related factors, such as CI. The study explored the relationships between CL and WOM promotion, and between CL and CI in the context of dental health clinics in Turkey.

Firstly, we tested the hypothesis that there is a positive relationship between CL and WOM promotion. This hypothesis was supported. The relevant literature indicates a strong relationship between CL and WOM feedback, and therefore our finding is consistent with the academic research, whose findings emphasize the importance of WOM communication for service firms. Although the literature on the relationship between CI and CL is mixed, we found a positive relationship between the two.

This study has several limitations. The first limitation relates to the fact that direct effects between the variables were examined, but indirect, mediating, and moderator effects were not. A second limitation relates to the sampling method. 


\section{REFERENCES}

[1] Jackson, T. (2011). The influence of traditional word-of-mouth, electronic word-of-mouth, and tie strength on purchase decisions (Order No. 1521967). Available from ProQuest Dissertations \& Theses Global. (1282658392). Retrieved from https://search.proquest.com/ docview/1282658392?accountid=15958

[2] Dick, A. S., \& Basu, K. (1994). Customer loyalty: toward an integrated conceptual framework. Journal of the academy of marketing science, 22(2), 99-113.

[3] Oliver, R. L. (1999). Whence consumer loyalty?. Journal of marketing, 63(4_suppl1), 33-44.

[4] Arndt, J. (1967). Role of product-related conversations in the diffusion of a new product. Journal of marketing Research, 291-295.

[5] Buttle, F. A. (1998). Word of mouth: understanding and managing referral marketing. Journal of strategic marketing, 6(3), 241-254.

[6] Goldenberg, J., Libai, B., \& Muller, E. (2001). Talk of the network: A complex systems look at the underlying process of word-of-mouth. Marketing letters, 12(3), 211-223.

[7] Chen, Y., \& Xie, J. (2008). Online consumer review: Word-of-mouth as a new element of marketing communication mix. Management science, 54(3), 477-491.

[8] Engel, J. F., Kegerreis, R. J., \& Blackwell, R. D. (1969). Word-of-mouth communication by the innovator. Journal of Marketing, 33(3), 15-19.

[9] Feldman, S. P., \& Spencer, M. C. (1965). The Effect of Personal Influence on the Selection of Consumer Services (pp. 440-452). Center for regional studies.

[10] Van den Bulte, C., \& Lilien, G. L. (2001). Medical innovation revisited: Social contagion versus marketing effort. American Journal of Sociology, 106(5), 1409-1435.

[11] De Bruyn, A., \& Lilien, G. L. (2008). A multi-stage model of word-of-mouth influence through viral marketing. International journal of research in marketing, 25(3), 151-163.

[12] Yeoh, E., Othman, K., \& Ahmad, H. (2013). Understanding medical tourists: Word-of-mouth and viral marketing as potent marketing tools. Tourism Management, 34, 196-201.

[13] Sharma, G., Qiang, Y., Wenjun, S., \& Qi, L. (2013). Communication in virtual world: Second life and business opportunities. Information Systems Frontiers, 15(4), 677-694.

[14] Michelle, H. (2006). Web word of mouth. Marketing Magazine, 111(25), 4-5

[15] Soares, A. M., Pinho, J. C., \& Nobre, H. (2012). From social to marketing interactions: the role of social networks. Journal of Transnational Management, 17(1), 45-62.

[16] Allsop, D. T., Bassett, B. R., \& Hoskins, J. A. (2007). Word-of-mouth research: principles and applications. Journal of Advertising Research, 47(4), 398-411

[17] Valck, K. D., Bruggen, G. H., \& Wierenga, B. (2009). Virtual communities: a marketing perspective. Decision Support System, 47(3), 185e203

[18] Gray, E. R., \& Balmer, J. M. (1998). Managing corporate image and corporate reputation. Long range planning, 31(5), 695-702.

[19] Lemmink, J., Schuijf, A., \& Streukens, S. (2003). The role of corporate image and company employment image in explaining application intentions. Journal of Economic Psychology, 24(1), 1-15.

[20] Wei, Y. C., Chang, C. C., Lin, L. Y., \& Liang, S. C. (2016). A fit perspective approach in linking corporate image and intention-to-apply. Journal of Business Research, 69(6), 2220-2225.

[21] Nguyen, N., \& Leblanc, G. (2001). Corporate image and corporate reputation in customers' retention decisions in services. Journal of retailing and Consumer Services, 8(4), 227-236.

[22] Eelen, J., Özturan, P., \& Verlegh, P. W. (2017). The differential impact of brand loyalty on traditional and online word of mouth: The moderating roles of self-brand connection and the desire to help the brand. International Journal of Research in Marketing, 34(4), 872-891. 
[23] Virvilaite, R., Tumasonyte, D., \& Sliburyte, L. (2015). The influence of word of mouth communication on brand equity: Receiver perspectives. Procedia-Social and Behavioral Sciences, 213, 641-646.

[24] Uslu, A., Durmuş, B., \& Taşdemir, S. (2013). Word of mouth, brand loyalty, acculturation and the Turkish ethnic minority group in Germany. Procedia-Social and Behavioral Sciences, 99, 455-464.

[25] Carpenter, J. M., \& Fairhurst, A. (2005). Consumer shopping value, satisfaction, and loyalty for retail apparel brands. Journal of Fashion Marketing and Management: An International Journal, 9(3), 256-269.

[26] Athavale, A. S., Banahan, III, B. F., Bentley, J. P., \& West-Strum, D. S. (2015). Antecedents and consequences of pharmacy loyalty behavior. International Journal of Pharmaceutical and Healthcare Marketing, 9(1), 36-55.

[27] De Matos, C. A., \& Rossi, C. A. V. (2008). Word-of-mouth communications in marketing: a meta-analytic review of the antecedents and moderators. Journal of the Academy of Marketing Science, 36(4), 578-596.

[28] Choi, B., \& Choi, B. J. (2014). The effects of perceived service recovery justice on customer affection, loyalty, and word-of-mouth. European Journal of Marketing, 48(1/2), 108-131.

[29] Kutluk, A., \& Avcıkurt, C. (2014). Ağızdan Ağıza Pazarlamanın Müşterilerin Satın alma Karar Süreçlerine Etkisi ve Bir Uygulama. Journal of International Social Research, 7(29).

[30] Uzunal, B., \& Uydacı, M. (2010). Sağlık kurumlarında ağızdan ağıza pazarlama ve bir pilot çalışma, Öneri. C.9. S.34. s: 87-95.

[31] Yıldız, S., \& Tehci, A. (2014). Ağızdan Ağıza İletişimde Müşteri Tatmini ve Müşteri Sadakati ile Mağaza İmajı Boyutları: Ordu İlinde Bir Uygulama. Atatürk Üniversitesi Sosyal Bilimler Enstitüsü Dergisi, 18(1).

[32] Öz, M., \& Uyar, E. (2014). Sağlık hizmetleri pazarlamasında algılanan hizmet kalitesi ve müşteri memnuniyeti üzerinde ağızdan ağıza pazarlamanın etkisini belirlemeye yönelik bir araştırma. Karamanoğlu Mehmetbey Üniversitesi Sosyal Ve Ekonomik Araştırmalar Dergisi, 2014(1), 123-132.

[33] Onurlubaş, E., \& Dinçer, D. (2016). Tüketicilerin Ağızdan Ağıza Ve Viral Pazarlama Algılarına Etki Eden Faktörlerin Analizi. Gümüşhane Üniversitesi Sosyal Bilimler Enstitüsü Elektronik Dergisi, C, 7, 17.

[34] Wang, C. Y., \& Wu, L. W. (2012). Customer loyalty and the role of relationship length. Managing Service Quality: An International Journal, 22(1), 58-74.

[35] Gürlek, M., Düzgün, E., \& Meydan Uygur, S. (2017). How does corporate social responsibility create customer loyalty? The role of corporate image. Social Responsibility Journal, 13(3), 409-427.

[36] Kipkirong Tarus, D., \& Rabach, N. (2013). Determinants of customer loyalty in Kenya: does corporate image play a moderating role?. The TQM Journal, 25(5), 473-491.

[37] Andreassen, T. W., \& Lindestad, B. (1998). The effect of corporate image in the formation of customer loyalty. Journal of Service Research, 1(1), 82-92.

[38] Kaur, H., \& Soch, H. (2013). Mediating roles of commitment and corporate image in the formation of customer loyalty. Journal of Indian Business Research, 5(1), 33-51.

[39] Lai, F., Griffin, M., \& Babin, B. J. (2009). How quality, value, image, and satisfaction create loyalty at a Chinese telecom. Journal of business research, 62(10), 980-986.

[40] Igbudu, N., Garanti, Z., \& Popoola, T. (2018). Enhancing Bank Loyalty through Sustainable Banking Practices: The Mediating Effect of Corporate Image. Sustainability, 10(11), 4050.

[41] Semerci, N. (2016) Sağlık İşletmelerinde Kurumsal İmajı Belirleyen Faktörler. Journal of Strategic Research in Social Science, 2(2), 17-38. 
[42] Marangoz, M., \& Akyıldız, M. (2007). Algılanan şirket imajı ve müşteri tatmininin müşteri sadakatine etkileri. Yönetim Bilimleri Dergisi, 5(1), 173-194.

[43] Aksoy, R., \& Bayramoğlu, V., (2012). Sağlık işletmeleri için kurumsal imajın temel belirleyicileri: Tüketici değerlemeleri. Uluslararası Yönetim İktisat ve İşletme Dergisi, 4(7), 83-94.

[44] Derin, N., \& Demirel, E. T., (2010). Kurum İmajının Kurum Kimliği Açısından Açıklanabilirliği: İnönü Üniversitesi Turgut Özal Tıp Merkezi Örneği. Hacettepe Sağlık İdaresi Dergisi, 13(2).

[45] Ferguson, R. J., Paulin, M., \& Leiriao, E. (2007). Loyalty and positive word-of-mouth: patients and hospital personnel as advocates of a customer-centric health care organization. Health marketing quarterly, 23(3), 59-77.

[46] Suki, N.M. (2011) “Assessing Patient Satisfaction, Trust, Commitment, Loyalty And Doctors' Reputation Towards Doctor Services" Pakistan Journal of Medical Science, 27(5): 1207-1210.

[47] Cho WH, Lee H, Kim C, Lee S, Choi KS., (2004). The impact of visit frequency on the relationship between service quality and outpatient satisfaction: A South Korean study. Health Serv Res. 2004 Feb;39(1):13-33.

[48] Ravichandran, N. (2015). Dimensions of patient loyalty and switching intention: Relational outcomes for benchmarking approach. International Journal of Healthcare Management, 8(4), 209-216.

[49] Nunnally, J.C. (1978). Psychometric Theory. McGraw-Hill, New York. 